\section{Szkicownik jako dokument autobiograficzny (XVIII/XIX wiek)}

\section{Elżbieta Wichrowska}

TEKSTY DRUGIE 2018, NR 6, S. 54-76

DOI: $10.18318 /$ td.2018.6.4
NARODOWY PROGRAM ROZWOJU HUMANISTYKI

Artykuł powstał w ramach projektu badawczego Między powstaniem a emigracja, Rysunkowy „pamiętnik” Piotra Michałowskiego $z$ r. 1832, finansowanego ze środków Narodowego Programu Rozwoju Humanistyki (nr 0249/NPRH4/ $\mathrm{H}_{1} \mathrm{~b} / 83 / 2015$ ).
Elżbieta Wichrowska

- prof. dr hab.; historyk literatury, edytor, kieruje Pracownią rękopisów i ineditów 1750-1850 na Wydziale Polonistyki UW. Autorka książek o kulturze polskiego Oświecenia i Wielkiej Emigracji. Ostatnio opublikowała książkę Marianna ż̇eglińskich Dembińska. Polskie początki buntu kobiet (2017). Obecnie przygotowuje publikację: Między powstaniem a emigracja, Rysunkowy "dziennik" Piotra Michałowskiego z roku 1832 (2019; wraz z Janem K. Ostrowskim). Kontakt: ewichrowska@

poczta.fm

1 Np. Nieborów (dalej NB). Al.8/1-49: Zielnik Elizy Radziwiłłówny (1803-1834 ) z lat 1818-1827. 
określenia definiujące jego specyfikę: „forma bez formy" ${ }^{2}$, „poetyka braku”, forma bez kompozycji „,konstruującej znaczenie całości" nadającej jej pewien sens globalny ${ }^{4}$, forma naznaczona fragmentarycznością, polimorficznością, polisemantycznością, heterogenicznością czy strzępowatością. O ile jednak badania związane z dziennikiem mają już za sobą kilkudziesięcioletnią tradycję, to szkicownik, pełniący przecież często także funkcję ważnego dokumentu życia osobistego, nie doczekał się tak rozwiniętej refleksji. Interesuje, co oczywiste, historyków sztuki, ale przede wszystkim jako dzieło ikonograficzne, związane z artystyczną aktywnością twórczą któregoś z artystów (najczęściej dobrze rozpoznawalnych). Do opisania pozostaje jednak fenomen XIX-wiecznej kariery szkicownika jako przedmiotu służącego odwzorowywaniu rzeczywistości, ale też utrwalaniu idei, myśli, uczuć czy ważnych wydarzeń z życia osoby go prowadzącej, co pozwala widzieć szkicownik także w perspektywie jednego z ważniejszych świadectw autobiograficznych.

\section{Szkicownik, czyli w poszukiwaniu cech dystynktywnych}

W słownikowych definicjach szkicownika (zarówno jako zbioru przedstawień graficznych czy też zbioru artykułów lub tekstów literackich) pojawiają się określenia akcentujące otwartość tej formy, jej ideowe i artystyczne niedomknięcie i niedopracowanie, typu: wstępne projekty, główne zarysy, treść ujęta w sposób ogólny, pierwsza realizacja koncepcji artystycznej. Ważną cechę określającą tożsamość szkicownika stanowi impresyjność tej formy (podobnie jak dziennika) budowanej rejestrem zapisów doznań, przeżyć, myśli, subiektywnych wrażeń naznaczonych momentalnością, dotyczących „tu i teraz", za którymi nie kryje się „fabularność" i - podobnie jak w dzienniku - podejście teleologiczne, systematyczne działanie, które ma określony punkt dojścia, cel, co zresztą wiąże się z kolejną ważną cechą szkicownika, jego charakterem użytkowym.

Tym, co nadaje szkicownikowi "gatunkową" tożsamość, jest przekaz ikonograficzny (szkic, rysunek, studium, akwarela, wycinanka itd.) jako

2 Opinię A. Girarda (Le journal intime et la notion de personne, Université de Paris, Paris 1963) przywołuje m.in. A. Milecki (Forma dziennika w literaturze francuskiej. Z dziejów form artystycznych w literaturze francuskiej, Daimonion, Lublin 1994, s. 110), a wcześniej M. Głowiński (Gry powieściowe. Szkice z teorii i historii form narracyjnych, PWN, Warszawa 1973).

3 Takuczyniłm.in. K. Adamczyk Dziennikjako wyzwanie. Lechoń, Gombrowicz, Herling-Grudziński, Parol, Kraków 1994, s. 18.

4 Na ten temat m.in. M. Głowiński Grypowieściowe..., s. 79-80. 
najważniejsza w zbiorze forma przekazu. Sam szkicownik, jako całość, kolejna forma bez formy, może być niemal wszystkim: może być zbiorem rysunków, szkiców, innych form graficznych, może być zbiorem projektów malarskich, rzeźbiarskich, planów architektonicznych, zbiorem semiotycznie jednorodnym (zawierającym wyłącznie przedstawienia ikonograficzne) albo też formą heterogeniczną, polimorficzną, zbiorem form artystycznych powiązanych tematycznie lub tylko miejscem zapisu ze słowem (podpisami powiązanymi z szkicami lub samodzielnie funkcjonującymi w szkicowniku zapisami ${ }^{5}$ ), zapisami liczbowymi (wyliczeniami, datami), nutami, wklejoną "rzeczą" - liściem, wstążką, puklem włosów6. Zapisami dopracowanymi albo niedokończonymi, właśnie „szkicowymi”, jednolitymi tematycznie albo nie, bez presji narzucającej tematykę, ta zależy wyłącznie od potrzeb użytkownika.

Istotną rolę odgrywa materialny kształt szkicownika. I nie chodzi tylko o typ wykorzystywanego materiału, o sposób „zapisu” („szybki” rysunek, szkic czy wymagająca więcej uwagi akwarela), choć to też istotne, ale w przypadku szkicownika ważne będzie to, co można by nazwać aktem zamknięcia dokonanym przez jego użytkownika. O ile dla tożsamości dziennika (czy pamiętnika) sprawą drugorzędną (w sensie tożsamościowym, "gatunkowym") jest to, czy prowadzony był na luźnych kartach, w przygotowanym wcześniej poszycie, zeszycie, bo najważniejsza dla jej określenia jest tu seria dat, one stanowią twardy wyznacznik „gatunkowy”, być albo nie być dziennika ${ }^{7}$ o tyle dla szkicownika istotne będzie zamknięcie

5 Szkicownikiem, w którym występują autonomiczne, nie powiązane ze sztuką notatki (np. Apteczka Domowa którą w niedostatku medyka snadno zdrowia człowiek poratować może ze wskazówkami typu: „Na bolenie zębów glisty ziemne w oliwie warzyć i w przeciwne ucho wpuszczać", s. 16) jest szkicownik Andrzeja Radwańskiego, który Z. Michalczyk nazywa "szkicownikiem i notatnikiem", odróżniając część graficzną od tekstów słownych oraz artystyczne od pozaartystycznych (Szkicownik i notatnik Andrzeja Radwańskiego. Z badań nad kulturq mieszczaństwa krakowskiego XVIII wieku, w: Między Wrocławiem a Lwowem. Sztuka na Śląsku, w Małopolsce i na Rusi Koronnej w czasach nowożytnych, red. A. Betlej, K. Brzezina-Scheuerer, P. Oszczanowski, Wydawnictwo UWr, Wrocław 2011.

6 Nie interesuje mnie tu szkicownik jako forma wypowiedzi wyłącznie literackiej, eseistycznej czy publicystycznej.

7 P. Lejeune (Koronka: dziennik jako seria datowanych śladów, "Pamiętnik Literacki” 2006 z. 4, S. 21) pisze: „Dziennik to seria datowanych śladów. Data wydaje się najważniejsza. Śladem jest z reguły pismo, ale może to być także obraz, przedmiot, prywatna świętość... [...] Dziennik zaczyna się, kiedy ślady ułożone są w serię i chcą raczej czas uchwycić w jego ruchu, niż zatrzymać przy jakimś istotnym wydarzeniu". 
właśnie w określonej ramie, materialnej klamrze: poszytu, zeszytu czy teczki ${ }^{8}$. Seria „luźnych" rysunków rozproszonych (nawet o wspólnej tematyce) nie jest szkicownikiem. Co więcej, spośród szkicowników wyodrębnić można prowadzone w gotowych „poszytach” i takie, w których akt zamknięcia dokonany został przez autora post factum. Przygotowane (być może) z tą myślą szkice były scalane, czasem oprawiane jakiś czas po ich wykonaniu, czasem dokonywano w nich właśnie wówczas dodatkowych wpisów, uzupełniano tekst czy daty. Dochodzi wówczas do ponownej autorskiej lektury (relektury) i aktualizacji szkiców, co zwłaszcza istotne w sytuacji, gdy nie były one wyłącznie próbami ręki i oka, ale miały charakter autobiograficzny.

Bardzo wygodny wydaje się podział szkicowników właśnie ze względu na ich użytkowników i, przede wszystkim, przeznaczenie, tj. na szkicowniki „zawodowe”, czyli szkicowniki ludzi sztuki: malarzy, architektów czy rzeźbiarzy, ale też inżynierów czy naukowców, a więc stanowiące rodzaj bazy danych, odwzorowników czy próby ręki i oka. Inną kategorię, mającą wiele wspólnego z „zawodowymi" szkicownikami, stanowią szkicowniki uczniowskie ${ }^{9}$, w tym tzw. wycieczkowe ${ }^{10}$, trzecią szkicowniki prywatne, zarówno artysty, jak i nie-artysty. Prywatne, a więc takie, których idea prowadzenia nie wynikała z założonych zadań zawodowych, bycia podstawą do dalszych realizacji artystycznych. Prywatny, a więc blisko związany ze swoim użytkownikiem, z jego potrzebami i psychiką, bardzo zróżnicowany pod względem funkcji i tematyki. W wielu brakuje zresztą dominanty tematycznej, ich użytkownicy odnotowują wszystko to, co autora zaciekawia, przyciąga jego uwagę i co wydaje mu się ważne: postaci, krajobrazy, architekturę, dzieła sztuki, zwierzęta, rzeczy czy sceny rodzajowe albo polityczne. To impuls, chęć rejestracji jakiegoś faktu z rzeczywistości (ale też świata wyimaginowanego) jest tu nadrzędna. Czasem tę obfitość organizuje biografia autora, który rejestruje w porządku chronologicznym ważne wydarzenia, rzeczy, miejsca ze swojego życia. Bywa też, że szkicownik jest

8 Muzeum Narodowe w Warszawie (dalej MNW) Rys.Pol.8898/1-18. Ciekawą formę "szkicownikową" stanowi pudełko zesłańca, Feliksa Zienkowicza (1842-1910) z Usoli (gub. Irkucka), o którym dalej.

9 Np. Zeszyt wzorów kaligraficznych uczniów Szkoły Pijarów (1762) MNW Rys.Pol.1656/1-45.

10 Nie chodzi tu jednak o szkicowniki prowadzone w trakcie podróży, które pełniły funkcje dzisiejszego aparatu fotograficznego, ale o te, które traktowano jako narzędzie edukacji; słowem wycieczka była po to, żeby szkicować, a nie odwrotnie. 
prowadzony w związku z zaistniałą sytuacją: podróżą, wycieczką, osadzeniem w więzieniu, zesłaniem na Syberię, pobytem w szpitalu. Do osobnej grupy należą różnego typu szkicowniki satyryczne (o profilu politycznym lub obyczajowym) czy też szkicowniki, w których przywołane wydarzenia z życia np. autorów układają się w pewne sekwencje obrazów z akcją, przypominając nieco historyjki obrazkowe, uznawane dziś za pierwowzory komiksów, szwajcarskiego rysownika i nowelisty Rodolphe’a Töpffera $(1799-1846)^{11}$.

\section{Popularność szkicownika}

Ważnym momentem w dziejach podręcznego szkicownika jest przełom XVIII i XIX wieku, to początek jego „innej” historii i niezwykłej kariery ${ }^{12}$. Od tego momentu znacznie zwiększa się i różnicuje grupa jego użytkowników, wśród których pojawiały się osoby różnych stanów, płci, wieku i zawodów, zaś jego upowszechnienie (już nie tylko jako rekwizytu zawodowego) wiązało się też $\mathrm{z}$ wykształceniem nowych funkcji i rozwinięciem nowych (w stosunku do przeszłości) typów szkicownika prywatnego.

Szkicują wówczas niemal wszyscy, co oczywiste malarze, tacy jak Norblin czy Michał Stachowicz, Marcin Zaleski, ale także tzw. amatorzy, i to nie tylko należący do elit, jak Jan Potocki i Juliusz Słowacki czy Fryderyk Skarbek. Szkicują arystokraci i przedstawiciele klasy średniej, mężczyźni i kobiety, szkicują też dzieci, młodsze i starsze, dorastające panienki, m.in. córka Heleny Radziwiłłowej, Krystyna (zapełniająca swój portefeuille szkicami z Kościuszką), lekcje rysunku pobierała też jej siostra, Rozalia, nie mówiąc już o trzeciej Radziwiłłównie, najbardziej z nich utalentowanej, Anieli, później Konstantowej Czartoryskiej, czy ich bratanicy, Elizie portretującej w Antoninie w swym szkicowniku Chopina. Szkicownik posiadał także syn Aleksandra i Anety z Tyszkiewiczów Potockich, wówczas 10-letni, August. Niektóre prowadzone były wspólnie, przez matki i ich dzieci, czasem nie obywało się bez pomocy guwernerów, inne dopełniało rodzeństwo lub bliskie właścicielom osoby

Töpffer w założonej przez siebie w 1824 roku genewskiej szkole - pensjonacie dla chłopców, wprowadził zwyczaj wędrówek z uczniami, podczas których w notatnikach notował, albo szkicował wrażenia z tych wypraw. Potem, od 1825 roku, przybierały one kształty cyklu opowiadań z podróży, początkowo adresatem była rodzina, przyjaciele i uczniowie (zob. A. Blondel Rodolphe Töpffer, l'écrivain l'artiste et l'homme, Librairie Hachette et Cie, Paris 1886, s. 375). 
spoza kręgu rodzinnego. O autorach wielu z szkicowników nic nie wiemy, pozostają anonimowi ${ }^{13}$.

W tym czasie, w pierwszych dziesiątkach XIX wieku, zaczynają szkicować także... literaccy bohaterowie, tacy jak Mickiewiczowski hrabia z Pana Tadeusza. Postać Hrabiego niemal nie rozstającego się ze swoim szkicownikiem, szkicuje wszystko, co przyciągało jego uwagę, co wzbudzało zachwyt i wyzwalało emocje dobrze ilustruje zjawisko ówczesnej popularności szkicownika, rozszerzenie jego funkcji, ale też użyty przez autora w tekście literacki szkicownik i szkicowanie stają się ważnym rekwizytem określającym osobowość bohatera (sentymentalno-romantyczną) ${ }^{14}$. Jest znakiem swoich czasów.

\section{Ekonomia - moda - potrzeba}

$\mathrm{Na}$ zwrot ku szkicownikom i upowszechnieniu ich użytkowania złożyło się wiele czynników, od ekonomicznych począwszy (np. tańszy papier), poprzez cywilizacyjno-kulturowe (np. powszechność podróżowania, w tym podróżowania naukowego i potrzeba rejestracji napotkanych „obiektów”, przy czym osobną odmianę stanowią tu szkicowniki z zesłania, syberyjskie ${ }^{15}$ ) po psychologiczne i związane z rozbudowywaniem w życiu jednostki, właśnie na przełomie XVIII i XIX wieku, sfery prywatnej. Niebagatelną rolę w tym procesie odegrała też moda na rysowanie/malowanie i miejsce, jakie zaczęli zajmować w tej przestrzeni amatorzy, słowem „demokratyzacja” i upowszechnienie, ucodziennienie czynności rysowania i malowania. To zjawisko, demokratyzacji, dobrze ilustruje lista uczestników warszawskich wystaw sztuk

13 Historia polskiego szkicownika, także jako dokumentu osobistego, czeka na swoje opracowanie. Jednym z problemów, które wiążą się tu z prowadzeniem badań, są źródła rozproszone między działami rękopisów, malarstwa, grafiki, w dodatku nie zawsze odpowiednio opisanymi w inwentarzach (lub nieopisanymi w ogóle).

14 To właśnie po nawyku szkicowania rozpoznał Sędzia, w jednym z oficerów armii generała Dąbrowskiego, Hrabiego. (A. Mickiewicz Pan Tadeusz, ks. XI, opr. K. Górski, Ossolineum, Wrocław 1969, s. 238.):

Dobyłz kieszeni portefeuille z plikami papierów, Rozłożyłje, ołówek przyciął, w ustach zmoczył, Patrzy w Zosię, rysuje. Ledwie Sędzia zoczył Papiery i ołówki, poznał rysownika; Choć go bardzo odmienił mundur pułkownika [...]

15 Np. MNW Rys.Pol.11732/1-26: Szkicownik (autor nieznany) z lat 1831-1835 z pobytu na Syberii, z widokami miejscowości, postacie mieszkańców, zwierzęta. 
pięknych zainicjowanych w 1819 roku $^{16}$. Biorą w nich udział zarówno profesjonaliści, jak i, przede wszystkim, amatorzy, wśród tych ostatnich znajdą się przedstawiciele niemal wszystkich stanów, wysocy urzędnicy i uczniowie, studenci uniwersytetu i innych szkół (od 1828 roku pojawiają się prace rysunki uczniów szkoły politechnicznej), w tym Instytutu Głuchoniemych ${ }^{17}$. Wyraźnie zaznacza się tu także obecność kobiet, uprawiających malarstwo zawodowo, dominują jednak amatorki w różnym wieku, o różnym statusie społecznym, od dam, takich jak hrabina Antonina Grudzińska, siostra księżnej Łowickiej, Zofia z Matuszewiczów, niegdyś podopieczna księżnej Izabeli Czartoryskiej, żona pułkownika (później generała) Ludwika Kickiego, która zaprezentowała na wystawie w 1821 roku dwa rysunki. Rok później 26 letnia wówczas Kicka odeszła z tego świata. Podobnie zresztą jak druga wychowanka księżnej Czartoryskiej, Aniela z Wierzchowskich, żona generała i poety Franciszka Dzierżykraj-Morawskiego, która dwukrotnie wystawiała swoje prace, w 1823 i 1825 roku. Ta zmarła w rok po swej drugiej wystawie ${ }^{18}$. Młode hrabianki, baronówny, jak Pelagia Soldenhoff, żony jenerałów i pułkowników stanowiły jednak mniejszość. W katalogach wystaw organizowanych w latach 20. (1819-1828) odnajdziemy obok tych już wymienionych nazwiska m.in. Karoliny Bledzewskiej (1819), Elżbiety Sałackiej (1823), Marianny Wyżewskiej (1823), Teresy Zbijewskiej (1823), Emilii Markendorf (1823), Emilii Kobylańskiej (1823 i 1825), Szokalskiej (1823) i Herman (1823; zapewne Maria z Tańskich, siostra pisarki, Klementyny), Aleksandry Lang (1825), Michaliny Bierzyńskiej (1825) i wiele innych. Wystawiano prace czasem bardzo młodych panienek, właściwie dzieci, jak Henryki Korytowskiej mającej lat 9 (1825, pojawia się też na wystawie w 1828). Niektóre, jak Dama Polska NN wolały pozostawać anonimowymi. Niektóre z tych amatorek z czasem zajmą się sztuką zawodowo, jak wystawiająca w 1825 roku ${ }^{19}$ piętnastoletnia baronówna Nina (Antonina) de Préchamps, późniejsza Hryniewicz (1809 lub 1810-1867) uczennica Ingresa. Osobną kategorię stanowiły grupy uczennic pojawiające

16 Na temat wystaw zob. Warszawskie wystawy sztuk pięknych w latach 1819-1845, opr. S. Kozakiewicz, Ossolineum, Wrocław 1952 (tu także katalogi i recenzje wystaw).

17 Uczniowie Instytutu pojawili się już na pierwszej wystawie, w 1819 roku. Jenerałowa Morawska we wrześniu 1823 roku została nagrodzona srebrnym medalem "3ciéy wielkości" "za twory sztuk pięknych wystawione w Salach Królewsko-Warsz. Uniwersyt" (w: Rocznik Instytutów religijnych i edukacyjnych, wyd. Jan Radomiński, Warszawa 1824, s. XVII).

19 Słownik artystów polskich i obcych w Polsce działających: malarze, rzeźbiarze, graficy, t. 8, red. J. Maurin-Białostocka i inni, Instytut Sztuki PAN, Wrocław 2007, s. 17. 
się na wystawach wraz ze swymi mistrzami, np. grupa Franciszka Brudera (1782-1838), do której w 1821 roku należały hrabianka Natalia Potocka,Zofia z hrabiów Chodkiewiczów Ossolińska, a także Angelika Trembicka i Marianna Skopowska. Zaś w 1828 roku z Henryką Beyer (1782-1855), która po śmierci męża (1819) w latach 1824-1833 prowadziła pierwszą na ziemiach polskich szkołę malarstwa i rysunku dla kobiet, wystawiały swoje prace jej uczennice, panna C... oraz Zofia Lessel. Kobiety nie tylko wystawiają prace na wystawach, ale też pojawiają się w tej roli w powieściach, tj. artystek amatorek wystawiających prace na pokazach publicznych, m.in. w Pamiętniku mtodej sieroty (1839) Pauliny Krakowowej (1813-1889) pisarki, publicystki i jednej z animatorek szkolnictwa dla kobiet. W jej powieści wystawa sztuk pięknych i decyzja o wystawieniu swych dzieł zmieni los osieroconej przez rodziców panienki.

Od trzech tygodni otworzono wystawę sztuk pięknych, Pani M. poradziła mi, aby kilka malowideł umieścić w tym zbiorze, Podbielska poparła jej radę dodając, że to jest najlepszy najstosowniejszy sposób okazania publicznie mego [...] talentu, i powiększenia dochodu, zgodziłam się więc na to, Pan B. wybrał cztery miniatury najtrafniejsze i najlepiej wypracowane [...] uległam potrójnej woli moich opiekunów i miniatury zawieszonemi zostały w Sali Kazimirowskiego pałacu. ${ }^{20}$

O tej literackiej, zapomnianej rzeczy Krakowowej warto pamiętać jeszcze z jednego powodu, w kontekście pojawienia się w polskiej literaturze powieści-dziennika, której początki sygnuje nazwisko Klementyny z Tańskich Hoffmanowej i jej Dziennik Franciszki Krasińskiej w ostatnich latach Augusta III pisany (1825). Czternaście lat później ukazała się kolejna napisana przez kobietę klasyczna polska powieść w formie dziennika, właśnie Pamiętnik młodej sieroty (1839).

W pierwszych dziesięcioleciach XIX wieku czynność amatorskiego rysowania, malowania wkracza na scenę publiczną i w tym sensie ulega, powtórzę, demokratyzacji. A w procesie upowszechnienia tej aktywności, co istotne, biorą udział kobiety - nieprofesjonalistki, dziewczęta, młodzież, nie tylko elity, słowem, niemal wszyscy. „Demokratyzacji” rysowania ulega także portefeuille. Przykład Mickiewiczowskiego Hrabiego - amatora niewypuszczającego swego szkicownika z dłoni wydaje się tu symptomatyczny: „Ale Hrabia 
nie słuchał, a pilnie rysowal"21. Upowszechnienie szkicowników, albumów, sztambuchów, artefaktów pamięci rysowników-amatorów staje się wówczas faktem kulturowym, i to o szerokim oddziaływaniu. I także w tej amatorskiej przestrzeni ich funkcjonowania, wyjściu poza krąg zawodowych rysowników/ malarzy ${ }^{22}$, poszerzeniu kręgu ich użytkowników i funkcji szkicownika można zaobserwować zjawisko upodobnienia formy dziennika i niektórych typów szkicownika. Szkicowanie staje się, podobnie jak nota w dzienniku, jedną z praktyk codzienności, działaniem, którego celem i efektem jest zapis doświadczenia teraźniejszości i które ma określony wymiar materialny. A gdy pod szkicami z pugilaresu pojawiają się daty, dystans między diariuszem a szkicownikiem bardzo się skraca, a w pewnym przypadkach przestaje istnieć. Obie formy łączy zestaw wielu analogicznych funkcji. Funkcją podstawową dla szkicownika była i jest nadal funkcja edukacyjno-ćwiczeniowa, nieobca też dziennikowi, związana z pracą nad sobą (także w sensie samodyscypliny, działań systematycznych) i własnym warsztatem artystycznym: ćwiczenie ręki i oka artysty, tworzenie zbioru pomysłów czy prób do dalszej realizacji. Ale też łączy je wiele innych funkcji od rejestracyjnych i memoryzacyjnych począwszy, a więc „świadka” i pamiętnika, przez rozrywkowe, po psychologiczno-terapeutyczne, gdy szkicownik staje się narzędziem autorefleksji, ale też autoterapii, psychologicznej wiwisekcji, mającej z jednej strony pomóc w zrozumieniu siebie (umacnianiać/rekonstruować własną tożsamość) i swoich emocji, sytuacji, z drugiej zaś oczyścić, pomóc w pozbyciu się emocjonalnego balastu. Szkicownik ma więc dokumentować życie prywatne użytkownika szkicownika, ma dokumentować i utrwalać rzeczywistość obyczajową, materialną, kulturową, polityczną (szkicowniki z podróży, satyryczne, wycieczkowe itd.), ale ta rejestracja, naznaczona emocjami autora, jego niedoskonałościami natury warsztatowej (co ważne przy kategorii tzw. amatorów), z założenia nie jest już prowadzona z myślą o dalszym przetworzeniu artefaktów, ale dla potrzeb osobistych. Prowadzenie szkicownika staje się właśnie wówczas, równolegle do prowadzenia dziennika, jedną z ważniejszych praktyk życia codziennego. Ważny był i nawyk, przymus rysowania, zapamiętywania rzeczywistości, jak u Mickiewiczowskiego Hrabiego z Pana

A. Mickiewicz Pan Tadeusz, s. 238.

Oczywiście, często jest wykorzystywany, wraz z obsadką z ołówkiem, jako element malarskich przedstawień, w tym autoportretów m.in. Norblina, Orłowskiego, Damela, Stattlera, a z późniejszych artystów, choćby Józefa Czapskiego, wskazujący na zawodową, malarską profesję autoportretowanego. 
Tadeusza, ale też sam nawyk szkicowania, prowadzenia szkicowników ${ }^{23}$ nie był bez znaczenia dla samego autora, wyostrzał bowiem widzenie, postrzeganie rzeczywistości.

Na popularność szkicowników i ich uprywatnienie miało wpływ coraz wyraźniejsze, na przełomie XVIII i XIX wieku, dochodzenie do głosu, w kulturze, piśmiennictwie (czas narodzin dziennika intymnego), ale i życiu jednostki przestrzeni intymnej i rodzącego się poczucia, że sprawy jednostki, indywidualne doświadczenia, ,moje sprawy”, ,moja pamięć”, „moje uczucia”, „moje przeżycia”, moja rodzina" stanowią wartość i godne są rejestracji, czy to diariuszowej, czy pamiętnikarskiej, także tej dokonywanej na kartach szkicownika, z czasem fotograficznej. Bo moment, w którym Mickiewicz wkłada szkicownik w dłonie Hrabiego, to moment poprzedzający oficjalne narodziny, pod koniec lat 30., fotografii, ziszczenie marzenia związanego z pragnieniem utrwalania "rzeczywistości” (ale pierwsze udane, po latach prób, zdjęcie Josepha Nicéphore'a Niépce'a pochodzi już z końca lat 20. z około 1827 roku).

Nie bez wpływu na ogromny przyrost tego typu wypowiedzi w polskim piśmiennictwie miała też sytuacja polityczna. „Prawdziwy koniec Królestwa Polskiego", czas wojen napoleońskich, w końcu, po 1831 roku, zesłania i exodus wychodźczy, potrzeba rozliczenia z rzeczywistością, lęk o przyszłość własną i najbliższych, rozłąka z rodziną i przyjaciółmi przekładały się na gwałtowny wzrost popularności form wypowiedzi z rozwiniętą funkcją pamięci, gatunków takich jak dziennik, pamiętnik i wspomnienie, a także list, zarówno w roli nośnika informacji, jak repozytorium pamięci. Pamięci indywidualnej, jednostkowej, subiektywnej, utrwalonej na fragmencie papieru, zapisanej, o wydarzeniach, ludziach, krajobrazach, rzeczach, drobiazgach codzienności, które w tych narracjach nabierają mitycznego wymiaru. Stają się czasem fragmentem utraconego raju.

Przestrzeń prywatna, intymna będzie zajmować coraz więcej miejsca nie tylko w dokumencie życia osobistego, ale i w przedstawieniach malarskich. Szkicownik, czyli portefeuille czy pugilares ${ }^{24}$, zaczyna oprócz narzędzia pracy

23 Halina Ostrowska-Grabska (Bric à bric 1848-1939, PIW, Warszawa 1978, s. 184): „Córka Wodnicy - obudziła mój dziecinny zachwyt, zapał i natchnienie ilustratorskie, także dziesiątki szkicowników zapełniałam... Wplatałam w nie mój naiwny zachwyt Primaverą Botticellego, zmieszany mimowolnie z echem obrazków z pisemka...".

24 Mickiewicz, pracując nad Panem Tadeuszem, nie użył jeszcze nazwy szkicownik, ale portefeuille. Także znacznie wcześniejszy Słownik /ęzyka Polskiego (1807-1814) S.B. Lindego nie rejestruje terminu szkicownik, ale pugilares (t. 2, cz. II, Warszawa 1811, s. 1271), jako rzecz do notowania, rysowania, rachowania. 
artysty, inżyniera i naukowca ${ }^{25}$ odgrywać ważną rolę w życiu przeciętnego inteligenta, stając się w jego ręku narzędziem rejestrowania (i poznawania) rzeczywistości. Jego prowadzenie, podobnie jak dziennika, traktować trzeba jako szczególną praktykę codzienności ${ }^{\mathbf{2 6}}$ opartą na zapisie momentalnym, nieciągłym, niedomkniętym, związanym z potrzebą chwili, zapisem, którego odbiorcą w założeniu ma być sam autor i jego bliscy.

U progu XIX wieku i w pierwszych jego dziesięcioleciach tematyka szkicownika, podobnie jak diariusza, wkraczała w przestrzeń osobistych doznań i notowań mających wartość przede wszystkim dla autora zapisków. Romantyczny duch indywidualizmu dotknął więc wnętrza szkicownika, jego tematyki, miejsca i roli w życiu jego użytkownika, także jako przedmiotu, rzeczy „noszonej przy sobie”. Ów indywidualizm z jednej strony, z drugiej zaś jego masowość będą określać typ szkicownika prywatnego, osobistego odgrywającego szczególną rolę w życiu jego autora. Do takich szkicowników należeć będą m.in. Celiny Treterów Dominikowskiej (ok. 1830-1908) Życie młodej dziewczyny od 1839 roku do 1853 w Łoni czy podgórski szkicownik Piotra Michałowskiego (180o-1855) z 1832 roku, a także więzienny szkicownik z 1864/1865 roku Alfreda Izydora Römera (1832-1897). Wyraźny w tych szkicownikach zwrot ku prywatności dyktowany był zarówno trudną psychologicznie sytuacją, w której artyści się znaleźli (Michałowski i Römer), ale też dokonującym się w całej kulturze europejskiej zwrocie „ku” prywatności, ku indywidualności, co znów miało wpływ na karierę szeroko rozumianego osobistego piśmiennictwa, wyraźnego zapotrzebowania na zapiski rejestrujące wydarzenia osobiste z życia autora i jego najbliższego kręgu albo też ukazujące historię przez pryzmat osobistych wydarzeń i zwią zanych z nimi emocji.

\section{Szkicownik z 1832 roku Piotra Michałowskiego}

Prowadzenie podgórskiego szkicownika przez Piotra Michałowskiego (przełom 1831 i 1832 roku), jednego z dziesięciu tego artysty, o których wiemy, przypada na moment szczególny zarówno w jego życiu, jak i sytuacji kraju, politycznego i psychicznego zawieszenia między klęską

25 Warto przypomnieć, że Bonaparte zadbał o to, by w korpusie ekspedycyjnym, który formował w związku z wyprawą egipską, nie zabrakło także rysowników i artystów kopistów.

26 Zob. P. Rodak Dziennik pisarza: między codzienna praktykq piśmienna a literaturq, „Pamiętnik Literacki" 2006 z. 4. 
powstania listopadowego a decyzją o emigracji. Michałowski, po zajęciu Królestwa przez Rosjan, dotarł na podkrakowskie Podgórze i dołączył do teścia, Antoniego Ostrowskiego, szukającego tu schronienia przed Moskalami, po upadku powstania. Na Podgórzu znalazły się także ich żony, Antonina z Michałowskich Ostrowska (wraz z dziećmi) i Julia z Ostrowskich Michałowska.

Użytkowany na Podgórzu szkicownik, składający się z 37 ilustracji umieszczonych na $38 \mathrm{kartach}^{27}$, nie jest zbiorem pojedynczych artefaktów, nie jest klasycznym roboczym notatnikiem, co pokazuje zestawienie go z pozostałymi zachowanymi szkicownikami artysty, o takim właśnie charakterze ${ }^{28}$, ale to mający własną „narrację” ikonograficzny zapis ówczesnej rzeczywistości, którą artysta chciał utrwalić, zapamiętać i z którą chciał się rozliczyć.

Pierwszy z jego trzech bloków tematycznych (codzienność podgórska, sceny powstańcze, pejzaże) tworzą wkraczające w sferę realiów życia codziennego kameralne sceny rodzinne rozgrywające się w wnętrzach podgórskich pomieszczeń. To sceny bliskie obcej przecież Michałowskiemu estetyce biedermeierowskiego salonu, realistyczne, pozbawione idealizacji, budowane domowym detalem (serwis do kawy, kieliszek, taca, fajka, sofa, stół czy krzesło), szczegółami codziennego ubioru (czepek na głowie kobiety, wstążka we włosach dziecka, laska w dłoni mężczyzny), a także prywatną, uchwyconą w naturalnych pozach, wręcz intymną przestrzenią rodziny. Wielokrotnie pojawia się postać żony, Julii, będącej już w zaawansowanej ciąży, co pokazuje jedno z jej przedstawień, w obszernym szlafroku z dłonią wysuniętą na zewnątrz i ułożoną na brzuchu w charakterystycznym, choć ledwie zaznaczonym geście. Pojawiają się postaci sióstr artysty, Antoniny Ostrowskiej czy Łucji Michałowskiej, teścia i szwagra, Antoniego i Stanisława Ostrowskich, a także siostrzenic i siostrzeńców oraz innych osób, zapewne z najbliższego otoczenia. Wszystkie ukazane zostały w codziennych sytuacjach: wspólnej kawy, rozmowy, udzielanej lekcji, palenia fajki, wykonywanej robótki ręcznej. W tym gąszczu osobistych przedstawień nie zabrakło też, co ważne, autoportretu samego Michałowskiego, tym samym

27 MNW Rys.Pol.7244/1-33. Temat szkicownika podgórskiego został szczegółowo opracowany w pracy: J.K. Ostrowski, E. Wichrowska Między powstaniem a emigracją. Rysunkowy "dziennik" Piotra Michałowskiego z roku 1832, Wydawnictwo Literackie, Kraków 2019 (w druku). Powyższy fragment nawiązuje do wspólnych ustaleń. 
artysta uczynił sam siebie elementem opisywanej w szkicowniku rzeczywistości i dał szkicownikowi stempel autobiograficzny ${ }^{29}$.

Ale na świat rodzinnej codzienności, biedermeierowskiej pozornej stabilizacji nakłada się inny, militarno-wojenny, powstańczo listopadowy (sceny bitewne, postaci dowódców, np. generała Dwernickiego z adiutantem, k. 5r, Antoniego Ostrowskiego w generalskim mundurze komendanta Gwardii Narodowej, k. 1r i 2r, oraz szeregowych żołnierzy różnych formacji), tworząc w szkicowniku szczególny palimpsetowy zestrój nakładających się na siebie obrazów, znaczeń, tematyk i estetyk. Sceny prywatne, z życia rodziny autora, twarze dzieci, ciężarna żona, rodzina pijąca kawę przy stole tworzą szczególny kontekst interpretacyjno-dokumentacyjny, ale i psychologiczny dla heroicznych przedstawień powstańczo-wojennych, jak ten z konnym krakusem atakującym lancą kawalerzystów rosyjskich i trupem Moskala u kopyt jego konia (k. 31r), zaś na przestrzeń osobistą patrzeć trzeba przez pryzmat umieszczonych w szkicowniku przedstawień militarnych. I to przemieszanie, nakładanie się na siebie tych dwóch przestrzeni, prywatnej i publicznej, stanowi jedną z najistotniejszych cech podgórskiego szkicownika. Istotna jest tu również decyzja autora o datowaniu i wskazaniu miejsca powstania niektórych szkiców, co nadaje szkicownikowi cechy diariusza. Data u dołu karty umocowuje te artystyczne przetworzenia rzeczywistości w Historii, narzuca konkretny kontekst ich lekturze.

Gdyby spojrzeć na szkicownik Michałowskiego z lejeunowskiej perspektywy „datowanych śladów" ${ }^{\text {"30 }}$, to datowania pojawiają się na kilku kartach (za to zarówno na "prywatnych", jak i powstańczych przedstawieniach) i obejmują zaledwie trzy dni: 15, 18 i 19 stycznia 1832 roku. Według Lejeune'a „pojedynczy, opatrzony datą ślad to raczej rzecz do zapamiętania, wspomnienie, rodzaj pamiętnika (mémorial), a nie dziennik. Dziennik zaczyna się, kiedy ślady ułożone są w serię i chcą raczej czas uchwycić w jego ruchu, niż zatrzymać przy jakimś istotnym wydarzeniu"31. A jeśli tak, to te trzy daty położone na sześciu kartach szkicownika zmieniają gatunkową tożsamość całego zbioru. Także te niedatowane rysunki pozostają w relacji z datami pojawiającymi się

29 „Dla autoportrecisty problem tożsamości ma dwa oblicza: autora i modela”, P. Lejeune Patrzq̨c na autoportret, w: Wariacje na temat pewnego paktu. O autobiografii, przeł. R. Lubas-Bartoszyńska, Universitas, Kraków 2001, s. 210. P. Lejeune Ciq̨głość i nie ciągłość. Dziennik jako seria datowanych śladów, w: „Drogi zeszycie...”, "drogiekranie......., s. 38. 
na sąsiednich kartach. Pamiętać też trzeba, że artysta bardzo rzadko datował swoje prace, opatrzenie rysunku datą ma więc podwójne znaczenie.

Szkicownik ten, tak ściśle związany z sytuacją polityczną, osobistą i psychologiczną autora i jego rodziny, stanowił próbę uchwycenia i utrwalenia (rejestracji i memoryzacji) szeroko rozumianego doświadczenia podgórskiego (którego elementem było również przeżycie i doświadczenie powstańcze). W szkicownikowym sfotografowaniu twarzy bliskich osób chodzi o zapamiętanie - zwłaszcza w kontekście zbliżającego się rozstania - ale też o autorefleksję, autoterapię, psychologiczną wiwisekcję, wyrzucenie z siebie emocji, słowem, próbę rozliczenia się z tym, co się wydarzyło i co ma się wydarzyć. Szkicownik Michałowskiego z przełomu 1831 i 1832 roku to także jeden z ważnych sposobów zdefiniowania własnego udziału w powstaniu listopadowym (ukazanym tu w wersji zwycięskiej), udziału w roli dyrektora fabryki broni, a więc udziału pozbawionego gestów heroicznych (które stały się elementem biografii niemal wszystkich młodych mężczyzn z rodziny artysty), a potem w podgórskim szkicowniku przypadła mu rola wyłącznie egzegety i interpretatora pamięci innych uczestników powstania.

Szkicownik podgórski nie jest więc jedynie ważnym dokumentem artystycznym, ale staje w szeregu obok form osobistych, takich jak diariusz czy list, pełni funkcję szczególnego zapisu autobiograficznego, a więc zapisu budowanego doświadczeniem autora, jego przeżyciami i związanymi z nimi emocjami.

\section{Szkicownik 1864/1865 Alfreda Izydora Römera}

Do grupy szkicowników, które nazwać by można artystycznymi transpozycjami doświadczenia niewoli należy o 30 lat późniejszy od podgórskiego, szkicownik więzienny Alfreda Izydora Römera, polskiego malarza, rzeźbiarza, medaliera, syna powstańca listopadowego. Szkicownik zawiera 43 rysunki wykonane w czasie pobytu autora w twierdzy dyneburskiej (1864-1865), do której trafił za udział w powstaniu styczniowym.

Ikonografię szkicownika podzielić można na trzy typy przedstawień. Pierwsze dotyczą rzeczywistości więziennej (cela, korytarze, widok dziedzińca, brama z mostem zwodzonym, zewnętrzny widok więzienia, tj. Wielkiego Ostrogu), drugie, osób z nią związanych (portrety więźniów, ale też Rosjan, wartowników, lekarzy i dowództwa), jeszcze inne opisują sytuacje (modlitwy więźniów; spacery po dziedzińcu; myszy wyłaniające się z nory w ścianie celi: „Pierwsi towarzysze”; więźniów wpatrujących się w kartkę trzymaną 
przez jednego z nich w dłoni „Kartka na widzenie się”; rosyjskiego żołnierza przygotowującego herbatę: „Panowi ja na herbatuju proszu /Dunajew służący żołnierz"). Ważną funkcję pełni tu szczegół, detal, ukazywany jako element większego przedstawienia, albo w ujęciach osobnych, jakby w zbliżeniu: okno z kratą, wizjer do drzwi celi, książka (Pan Tadeusz), różaniec, przedmioty codziennej higieny: lusterko, szczotka do włosów, zużyte, rozdeptane półbuty i trzewiki, czajniczek do herbaty, obok szklanka na spodku z łyżeczką w środku i świeczka w niskim lichtarzu postawione na mocno sfatygowanej torbie przykrytej kawałkiem chusty (serwety?) i podpis: „Stolik na herbatę”.

Szkicownik Römera nie jest wyłącznie klasyczną próbą skalkowania rzeczywistości. To przede wszystkim próba stekstualizowania własnego, indywiduanego doświadczenia więziennego, które jest jednocześnie przeżyciem wielu, doświadczeniem wspólnoty dyneburskiej, w dodatku stanowiącym ważny element doświadczenia narodowego. Przynależy do Wielkiej Historii, ale w szkicowniku ta ukazana została z perspektywy konkretnej biografii, co zresztą obrazuje chronologiczna kompozycja szkicownika, (nb. układ rysunków w szkicowniku zaprojektowany został przez autora, już po wyjściu $\mathrm{z}$ więzienia).

Szkicownik otwiera ilustracja przedstawiająca unoszącego się Anioła z księgą O naśladowaniu Jezusa Chrystusa (k.1, il. 1), na kolejnych kartach znalazły się: autoportret Alfreda Römera z podpisem „15 marca r. $1864 \mathrm{w}$ fortecy Dyneburskiej” (k. 2, il. 2) oraz dwa rysunki „więzienne” wklejone jeden pod drugim (k. 3). Pierwszy (il. 3) z celą: niską, piwniczną z półokrągłym sufitem, wysoko umieszczonym zakratowanym małym oknem w kształcie trójkąta, trzema drewnianymi pryczami, na jedną rzucono skórzaną torbę i worek podróżny, w rogu rysunku widać fragment metalowego łóżka przykrytego kocem, obok niego męskie trzewiki. Z drugiego rogu wyłania się fragment zbitego z desek, podobnie jak prycze, stołu, na nim czajniczek na herbatę, cukiernica, szklanka na spodku, talerzyk na zmiętym fragmencie materiału służącym za serwetę. Ściany ktoś ozdobił rysunkami. Pod ilustracją dodano podpis: „Przesiedziałem tutaj od 14 lutego do 21 marca r. 1864. Mikołajewska kazamata w fortecy Dyneburskiej (il. 3), rysunek wklejony poniżej, z widokiem bramy twierdzy dyneburskiej, (il. 4), także komentuje podpis: „Widok Nikołajewskiej bramy, Więzienie moje i Xdza Michała Skorupskiego" (il 4). Już te dwa szkice i, zwłaszcza umieszczone pod nimi słowne komentarze, nadają szkicownikowi charakter wypowiedzi osobistej. I co kilka kart, między odnotowywanymi w tym ikonograficznym zapisie detalami powszechnej więziennej rzeczywistości pojawiać się będzie bardzo wyraźne „ja” autorskie. 
Zachowała się jeszcze jedna wypowiedź autobiograficzna Römera dotycząca tego właśnie okresu, pozwalająca lepiej zrozumieć sens ilustracji zamieszczonych w szkicowniku, dookreślić to, co można by nazwać jego komponentem autobiograficznym, zrekonstruować proces i czas powstawania kolejnych jego przedstawień czynionych w większości de visu. To fragmenty wspomnień Römera publikowane przez Henryka Mościckiego w kolejnych numerach „Tygodnika Ilustrowanego" z 1912 roku (autograf pamiętników spłonął w czasie II wojny), w których znajdują się m.in. komentarze do pierwszych rysunków szkicownika z widokiem celi w Mikołajewskiej kazamacie i bramy twierdzy z mostkiem przerzuconym przez fosę.

Tem więzieniem była znana "Nikołajewskaja kazamata” w bramie, pod wałem fortecznym, nad kanałem zapełnionym wodą. Wtrącono mię do jakiegoś lochu - drzwi żelazne zgrzytnęły, zamykając się za mną na zamek. Zostałem sam w absolutnej ciemności. Nieprędko mi przyniesioną zapaloną łojówkę bez lichtarza $[\ldots]^{32}$

Wspomnienia te rozwiązują też zagadkę rysunków na ścianach celi w „nikołajewskiej kazamacie":

Po kilku dniach samotnych rozmyślań nad niepewnym mym losem, zacząłem wynajdywać rozmaite zajęcia. Ściany mego obszernego więzienia postanowiłem upiększyć freskami swego rodzaju; do tego mi służyły węgle, tarta cegła i przypadkiem znaleziona w mej walizce farbka do bielizny. [...] Dzięki uprzejmości plac-majora Basowa otrzymałem ołówki i papier, mogłem więc z czasem i wnętrze mego podziemia wyrysować [...] Tymczasem w podziemiu coraz mi więcej przybywało zajęcia. $\mathrm{Pa}-$ pier i ołówki do tego mi najwięcej pomagały, bo książek mi żadnych nie dawano. ${ }^{33}$

Cykl szkiców otwierają więc te bezpośrednio dotyczące sytuacji ich autora, w kolejnych to autobiograficzne „ja” przeplatać się będzie z „my” czy „oni”, ale też wyeksponowanym światem rzeczy, o czym była już mowa. Do tych pierwszych należy m.in. rysunek przedstawiający więzienny korytarz, dwie postaci, jedna na kolanach, modląca się przy służącym za klęcznik stołku, druga oparta 
o ścianę i zapatrzona w dal, a pod nim podpis „Korytarz i drzwi mojej celi w Wielkim Ostrogu” (il. 13). To „ja” wybrzmiewa mocno także w rysunku o ciekawej, wielopoziomowej budowie przybierającej formę poliptycznych fragmentów (il. 12).

Ze wspomnień wiadomo, że po 36-dniowym zamknięciu w odosobnieniu, w lochach Nikołajewskiej Kazamaty Römer, 21 marca, został przeniesiony „na górę", do Wielkiego Ostrogu, gdzie przebywała reszta więźniów w zdecydowanie lepszych warunkach ${ }^{34}$. Sytuację w tym nowym miejscu przedstawia, wspomniana wyżej, ,poliptyczna” ilustracja. Jej centrum stanowi pusta cela z pościelonym łóżkiem i pryczą, piecem, dwoma kapeluszami zawieszonymi na ścianie, stół, na nim otwarta książka i paląca się świeca z podpisem „Wnętrze celi mojej i Franciszka Karnickiego". Rysunek ten okalają dodatkowe ilustracje z życia więziennego: kartusz z drutu kolczastego z rokiem 1864, zawieszony na ścianie różaniec, książka Pan Tadeusz, bukiet kwiatów, wróble, Ossędowski podgrzewający w piecu posiłek („Dzieci stół nakrywać”), służący (Dunajew) z samowarem, o którym była już mowa, wpatrzeni w „kartkę na widzenie się" czy modlący się więźniowie („Godzina 11 rano. Ks. Michał Skorupski czytał głośno modlitwy w Wielkim Ostrogu, forteca Dyneburska"). I znów, w tym ostatnim przypadku, widać paralele między ilustracją, podpisem pod nią a fragmentem cytowanych już tu wspomnień Römera: „Dnia 2 (14) kwietnia rozstrzelany został więzień stanu, Przemysław Kołb. Wszyscyśmy podczas egzekucji klęcząc odmawiali modlitwy za konających"35.

Istotnym, także ze względu na liczbę przedstawień, fragmentem szkicownika są portrety (czasem zbiorowe) i sylwetki osób spotkanych w twierdzy. Nie są to twarze anonimowe, większość z nich opatrzona została nazwiskiem portretowanej osoby i, najczęściej, dodatkową informacją: „,uwolniony”,,,wygnany”, ,na Syberię" oraz, czasem, komentarzem zamieszczonym u dołu karty wskazującym na osobistą relację autora „Koledzy z Wielkiego Ostrogu” (k. 14). Do takich należy też ilustracja ukazująca więźniów w „Szpitalu Dyneburskim r. 1864", w którym, wiadomo ze wspomnień, przebywał autor. Ten więzienny cykl rysunków i akwareli Römera zamykają dwa szczególne artefakty. Pierwszy przedstawia pustą celę: metalowe łóżko z odrzuconym kocem i świeżym wgnieceniem na poduszce, jakby ktoś przed chwilą je opuścił. Pośrodku stołu, czy raczej stolika, przykrytego białą serwetą stoi duży krzyż-krucyfiks, po

34 Tamże, 1912, t. 33, s. 684 .

35 Tamże. „To był drugi spełniony wyrok śmierci na więźniu stanu, więcej się już one nie miały powtórzyć za mej bytności w fortecy dyneburskiej". 
jego obu stronach postawiono dwie świece. Przed krzyżem leży stuła, część jej zwisa z obrusu, jej fragment przykrywają wsparte o nasadę krzyża dwie książki, większa i mała, zapewne biblia i modlitewnik. Przez okratowane okno dostał się do celi promień słoneczny. I podpis: „Hrabia Leon Plater +8 czerwca/28 maja w Dyneburgu/rozstrzelany w r. $1863^{36}$. Römer nie był świadkiem tej egzekucji, do twierdzy trafił niemal rok później". Kolejny i ostatni zarazem rysunek zamieszczony w szkicowniku składa się z „masy” nieregularnych kresek rzuconych na papier, ale z tej sieci nerwowych śladów ołówka, tak wyróżniających się spośród reszty precyzyjnych, wykończonych, domkniętych rysunków szkicownika, wyłania się coś na kształt półkolistego sklepienia celi, obrysu wejścia do niej. To epilog, zamknięcie szkicownika, ale też historii Leona Platera i innych więźniów stanu. Zachowała się relacja Eugeniusza, brata Leona z ostatniego dnia i godzin jego życia, znakomity komentarz do szkicownikowego epilogu Römera „Leon został nagle pod silną eskortą przeprowadzony [...] do więzienia w fortecy pod Nr 1, gdzie zwykle ostatecznie umieszczano nieodwołalnie na śmierć skazanych. Tam mu (26-go maja [...]) oznajmiono, żeby był gotów, bo nazajutrz rano miał być stracony; znaleziono go spokojnie piórkiem rysującego na papierze [sic!]; prosił o księdza, przyzwolono na to i pełniący obowiązki proboszcza ks. Bolesław Aleksandrowicz (w późniejszym czasie skazany na ciężkie roboty i zmarły po drodze w Tiumeniu) otrzymał pozwolenie od komendanta spędzenia z nim nocy przedśmiertnej. W największym skupieniu na ciągłej modlitwie przy rozmowie w wyższym nastroju duchowym zeszła ta noc ostatnia. Leon się spowiadał, otrzymał ostatnie sakramenta $[\ldots]^{38}$. Kolejne, po ostatnich ilustracjach, wklejone karty szkicownika stanowią jakby aneks do części ikonograficznej. To papier nutowy z nutami (bez słów) „Arii śpiewanej przez więźniów - pisał Ignacy Zaleski”, to „Lista osób, których portreta robiłem

36 Leon Plater został ujęty po udziale, 25 maja 1863 roku, w ataku na transport broni. Wziął na siebie całą winę za jego organizację. Zwłoki rozstrzelanego 27-letniego Platera pochowano w miejscu stracenia, mogiłę stratowano. Nocą jednak ciało przewieziono w nieznane miejsce; nie wydano go matce mimo jej interwencji, także u cesarzowej. Zob.: W. Studnicki Rok 1863. Wyroki śmierci, Chomiński Ludwik, Wilno 1923, 87a-92b.

37 Wśród ilustracji związanych z przestrzenią więzienną znalazło się kilka "wyimaginowanych", np. "Żony Mężowie" (płaczące kobiety i dzieci przy chacie, a w drugiej części rysunku, mężczyźni przy stole, w pomieszczeniu z kratami, a między nimi, żonami i mężami, rosyjski żołnierz (il. 11).

38 Wspomnienia Eugeniusza Broela Platera, brata Leona, cyt. za: W. Studnicki Rok 1863..., s. 89b-90a. 
w Dyneburgu... (w ogóle portretów 68)", a poniżej spisu znalazł się „Plan Wielkiego Ostrogu", precyzyjny, z zaznaczeniem obrysu murów, bramy, wałów fortecznych, korytarzy, wejść, dziedzińca i wreszcie wszystkich cel I i II oddziału, w tym celi własnej, o której mowa w legendzie do planu ${ }^{39}$ : „I Oddział No 8. Moja cela od 21 marca r. 1864 do 12 Sierpnia r. 1865. I Odział No 9 Telesfor Nieszokeć rozstrzelany pod imieniem Budrysa 3 marca 1864. N 10 Hr Leon Plater rozstrzelany Maja 27 r. 1863. II Oddział N5. Przemysław Kołb rozstrzelany 2 kwietnia r. 1864". Szkicownik - więzienny notatnik Römera zamykają kartka z ekspensami za miesiąc lipiec oraz mapa, to ostatnia karta szkicownika, „Kostromska Gubernia, do której miałem być wysłany na wygnanie".

Szkicownik Römera nie stanowi odmiany dziennika. Większość ilustracji nie nosi dokładnych dat (czasem pojawia się rok, bywa, że i miesiąc) wskazujących na konkretny moment ich sporządzenia. Z drugiej strony ilustracje, w każdym razie większość z nich, wykonywane de visu, stanowią reakcję na sytuację, są relacją z „tu” i „teraz”, a to zbliża szkicownik Römera do narracji diariuszowej. Wiadomo, że rysunki i akwarele wklejane były do „szkicownika” już później, zapewne też część wpisów pochodzi z późniejszego okresu, choć niewykluczone, że przynajmniej niektóre opatrywał od razu komentarzem. Włączył też 9 zdjęć rzeźb („kopie z moich rzeźb na drzewie”) zapewne wykonanych w więzieniu. To m.in. „fotografia noża do rozcinania kart dla Mamy” $\mathrm{z}$ wyrytym rokiem 1864, z drugiej strony drewnianego noża widoczny jest napis: Dyneburg, a na nim łańcuch z kłódką. To połączenie rysunku, spełniającego przecież funkcję fotografii i samej fotografii jest działaniem ważnym, zmieniającym tożsamość tego szkicownika, który dodatkowo nabiera pewnych cech albumu. Etap powstawania szkicownika, nazwijmy go drugim, selekcjonowania (?), zbierania w całość i uzupełniania wiązał się z procesem aktualizacji, już po opuszczeniu więzienia, tego, co działo się w twierdzy dyneburskiej, ponownego przeżycia i formą autoterapii.

Ważne jest również to, że autor zachował, wklejając rysunki do „albumu” kolejność odpowiadającą chronologii jego pobytu w Dyneburgu, zapewne też powstawania szkiców ${ }^{40}$. Tym samym szkicownik tworzy paralelę do

39 Także we wspomnieniach opisał wygląd Wielkiego Ostrogu i podał nazwiska umieszczonych w kolejnych celach więźniów.

40 Na wielu szkicach pojawia się rok i miesiąc ich powstania (bez dnia). Widać pewne zaburzenie chronologii, np. portret (il. 24) Karola Falewicza, "r. 1864 grudnia z Dyneburga” znalazł się między portretami z roku 1865 . 
Wspomnień czy, odwrotnie, wspomnienia do szkicownika. Część materiałów pochodzi z okresu pobytu w twierdzy, część, jak np. mapa, zdjęcia dodane zostały później. Możemy więc w tym wypadku mówić, że pierwszy etap wiązał się z funkcją i próbą niemal fotograficznej rejestracji i zapamiętania, także poprzez podpisy pod ilustracjami, miejsc, ludzi, sytuacji, i to w porządku chronologicznym. Szkicownik Römera stanowi więc odpowiednik pamiętnika (ciekawe w tym kontekście jest włączenie tu fotografii), jest, ze względu na tematykę, miejscem pamięci szczególnej, uświęconej męczeństwem. Miejscem sacrum. Podpisy: „uwolniony”, „wygnany”, ,na Syberię”, „stracony” pod portretami, które nb. stanowią znakomity i rzadki dokument ilustracyjny, ukazują twarze ludzi najczęściej nieznanych, otwierają inną historię zwykłych uczestników powstania, inną już opowieść, która często będzie miała swoją kontynuację szkicownikową, myślę o szkicownikach syberyjskich (m.in. Maksymiliana Oborskiego z 1867 roku $^{41}$ albo o pudełku Feliksa Zienkowicza (1842-1910) zesłanego na Syberię do Usola (gub. Irkucka). Na ściankach pudełka na planie ośmiokąta, z podwójnym dnem, wykonano pejzaże Usola portrety strażników, a także rysunki przedmiotów symbolizujących zesłanie: łopata, kilof, siekiera, młot oraz kajdany. Na spodzie pudełka ukryta została, i przykryta podwójnym dnem, datowana lista zesłańców pracujących w tamtejszej warzelni soli: 29/16 sierpnia ${ }^{42}$.

Powstanie szkicownika zarówno Michałowskiego, jak i Romera wiązało się z konkretną, niezwykle trudną psychologicznie, sytuacją w ich życiu, którą chcieli opisać, utrwalić, zapamiętać i odreagować. Inny już charakter ma prowadzony przez prawie 15 lat szkicownik Celiny z Treterów Dominikowskiej (ok. 1830-1908) Życie młodej dziewczyny od 1839 roku do 1853 w Łoni ${ }^{43}$, z 117 rysunkami rejestrującymi miejsca, postaci i wydarzenia z lat dzieciństwa i nauki oraz wkraczania w dorosłość panienki, potem młodej kobiety z okolic Lwowa: pejzaże, wnętrza, spotkania, bale, rozmowy, prace domowe, ale też wiele z nich dotyczy kwestii politycznych, zwłaszcza tych z roku 1848, m.in. ilustracja przedstawiająca grupę debatujących mężczyzn. Rysunek został uzupełniony podpisem: Wolność, równość, braterstwo! Konstytucja 19 marca ${ }^{44}$.

41 MNW, Rys.Pol.639o/1-81, Szkicownik syberyjski z roku 1867 Maksymiliana Oborskiego (1809-1878).

MNW Rys.Pol.8898/1-18.

BN, AFRys. 15/l. Wersja cyfrowa: https://polona.pl/item/pamietnik-rysunkowy-inc-zycie-mlodey-dziewczyny-od-1839-roku-do-1853-w-loni,MjUoMzU5ODU/4/\#item. 
Daty zamieszczane w szkicowniku Celiny Dominikowskiej najprawdopodobniej wskazują nie tyle moment zapisu (jak w szkicowniku Michałowskiego), ile czas dokumentowanego wydarzenia. A jeśli tak, to szkicownik Celiny trzeba by widzieć nie tyle w perspektywie świadomie budowanej relacji diariuszowej, co pamiętnikarskiej. Podobnie jednak jak w szkicowniku Michałowskiego i Römera, bardzo wyraźnie daje tu o sobie znać czynnik autobiograficzny, podkreślony także i tu autoportretem otwierającym cykl ilustracji i narzucającym perspektywę postrzegania i opisu świata przyjętym w tym szkicowniku.

Celina Dominikowska, podobnie jak Alfred Izydor Römer (nb. niemal równolatkowie) czują potrzebę ciągłej rejestracji wydarzeń, za pomocą różnych znaków i form (ikonograficznych, literackich). Czują potrzebę rejestrowania wydarzeń ważnych dla ogółu, ale z uwzględnieniem indywidualnej perspektywy. Własna biografia, życie rodziny stają się w przywołanych szkicownikach, powtórzę, elementem Wielkiej Historii.

Szkicownik w II połowie XVIII wieku i pierwszych dziesiątkach XIX dołącza do niezwykle modnych relacji „o sobie”, które zapełniają wówczas już powszechnie dzienniki i pamiętniki. Michałowski, Römer, Dominikowska to tylko kilka ze znacznie większej liczby przykładów zwrotu ku sobie. Wcześniejszym przykładem, z II połowy wieku XVIII, takich relacji z wyeksponowanym wątkiem autobiograficznym były szkicowniki Daniela Chodowieckiego (1826-1801) używane podczas jego podróży z 1773 roku z Berlina do rodzinnego Gdańska (zwane przez niego książeczkami) ${ }^{45}$, w których artysta rejestrował sytuacje, postaci z kręgu rodzinnego, a także sylwetki mieszkańców Gdańska, rzadziej, choć także, architekturę, tworząc typ ilustrowanego diariusza (nb. równolegle do szkicowników prowadził zresztą dziennik podróży $\left.{ }^{46}\right)$.

W szkicownikach prywatnych, które nie były prowadzone z myślą o dalszych rozwinięciach artystycznych, ale stanowiły szczególne repozytorium

45 K. Zabuska Daniel Mikołaj Chodowiecki - czołowy ilustrator niemieckiego oświecenia, w: Ryciny szkoły niemieckiej od końca XV do początku XIX wieku. Cześć 2. Ryciny Daniela Chodowieckiego, Muzeum Narodowe w Gdańsku, Gdańsk 2015, s. 18.

M.in. D. Chodowiecki Von Berlin nach Danzig: eine Künstlerfahrt im Jahre 1773, Verlag von Amsler \& Ruthardt, Berlin [1883]; tegoż Dziennik z podróży do Gdańska z 1773 roku, oprac. i przeł. M. Paszylka, Oficyna Wydawnicza FINNA Muzeum Narodowe w Gdańsku, Gdańsk 2002. Na temat Gdańska w szkicach Chodowieckiego: M. Dębowski Les vues de Gdańsk dans la peinture de Daniel Chodowiecki et Fryderyk August Lohrmann, konferencja "La mer : fictions, pouvoirs, identités „Université Bordeaux Montaigne/SIEDS, 24 août 2018. 
pamięci, coraz ważniejszą rolę, oprócz daty, pełni komentarz słowny. Sam szkic, rysunek nie zawsze już wystarcza, by odpowiedni, zaprojektowany przez autora przekaz dotarł do odbiorcy (którym może być również on sam). Postaci, o których mówi, sytuacje, miejsca ważne w perspektywie życia (jak u Dominikowskiej), ale też u Römera, konkretnej jednostki domagają się słownego dookreślenia, konkretyzacji. Z czasem powstawać z tego typu korelacji, szkicu i tekstu zaczną całe opowieści mające charakter wpół- lub całkowicie autobiograficzny, z pewną fabułą, dając początki komiksowi, jak w przypadku Wandalina Strzałeckiego (1855-1917). Od 1885 roku artysta przebywał aż do śmierci, cierpiąc na ciężką postać choroby psychicznej, w Zakładzie Jana Bożego w Warszawie. Z tego okresu i tego miejsca także pochodzi szereg szkicowników Strzałeckiego ${ }^{47}$. Z czasów sprzed szpitala Jana Bożego zachowały się jego dwie serie komiksowe: Przygody pewnego srogiego, stawetnego - rzadkiego -rarytnego $i$ ! ... ukochanego artysty... Wandziusia Stodkiego ${ }^{48}$ oraz szkicownik ze scenkami humorystycznymi, często nasyconymi erotyzmem, pełnymi scenek rodzajowych Całe życie cierpień, a kwadrans radości,... czyli dola Wandziowa, których bohaterem jest Wanduś, dziecko, młodzieniec i w końcu artysta. Na pierwszej karcie drugiego z szkicowników znalazł się komentarz: „Wandziem nazywali koledzy artyści nieszczęśliwego Wandalina Strzałeckiego". Całe życie cierpień... jest to autobiografia humorystyczna, ze skarykaturowanym autoportretem głównego jej „bohatera” występującego we wszystkich niemal szkicach, jakie zeszyt ten zawiera"49.

Do tego typu szkicowników, opowieści należeć będzie także szkicownik z 1877 roku Michała Piotra Radziwiłła (1853-1903) Moje przygody u Stryja spisane i ilustrowane za dobrych czasów podczas wieczorów w Nieborowie ${ }^{50}$ (1877) czy Par Łowicz à Nieborów.

$\mathrm{Z}$ czasem proporcje między słowem i rysunkiem, w prywatnym szkicowniku, zaczną się wyraźnie przesuwać w kierunku tego pierwszego, nie słowo będzie dookreślać tekst ilustracyjny, ale ten uzupełniać warstwę tekstową, interakcje wewnątrzszkicownikowe zmienią się, podobnie jak i jego funkcje.

\footnotetext{
47 MNW Rys.Pol.8973/1-21; Rys.Pol.8974/1-20; Rys.Pol.8975/1-6. 


\section{Abstract}

\section{Elżbieta Wichrowska}

UNIVERSITY OF WARSAW

The Sketchbook as an Autobiographical Document (Eighteenth/Nineteenth Century)

Wichrowska describes the breakthrough that took place in the history of the sketchbook at the turn of the nineteenth century, when the sketchbook - previously a professional prop - became an artefact of individual memory. This transformation was accompanied by a turn towards private life, a democratization in the use of sketchbooks (in terms of social spheres, gender and themes), popularization (sketchbooks became ubiquitous, also in fiction), a marked expansion in the sketchbook's function (related to memory and resembling a personal diary), while new"autobiographical" forms emerged. Wichrowska contextualizes this turn to private life with social and cultural changes, including women's participation and fine art exhibitions in Warsaw. She presents hitherto unknown sources, such as sketchbooks-journals (by Piotr Michałowski, Celina z Treterów Dominikowska), prison sketchbooks (by Alfred Römer), Siberian sketchbooks and comic sketchbooks (Michał Piotr Radziwiłł; Wandalin Strzałecki).

\section{Keywords}

sketchbook, diary, journal, photography, turn to private life, turn of the nineteenth century, artefacts of memory, fine art exhibitions in Warsaw 